Towards a global environmental sociology? Legacies, trends and future directions
2015, Vol. 63(3) 339-368

(C) The Author(s) 2014

Reprints and permissions:

sagepub.co.uk/journalsPermissions.nav DOI: 10.1।77/001।3921।4543537

csi.sagepub.com

\title{
Rolf Lidskog
}

Örebro University, Sweden

\section{Arthur PJ Mol}

Wageningen University, The Netherlands

\section{Peter Oosterveer}

Wageningen University, The Netherlands

\begin{abstract}
A current debate on environmental sociology involves how the subdiscipline should conceptualise and investigate the environment and whether it should be prescriptive and deliver policy recommendations. Taking this debate as a point of departure this article discusses the current and future role of sociology in a globalised world. It discusses how environmental sociology in the US and Europe differ in their understandings of sociology's contribution to the study of the environment. Particular stress is placed on how these two regions differ with respect to their use of the tradition of sociological thought, views on what constitutes the environment and ways of institutionalising environmental sociology as a sociological field. In conclusion, the question is raised of whether current versions of environmental sociology are appropriate for analysing a globalised world environment; or whether environmental sociology's strong roots in European and US cultures make it less relevant when facing an increasingly globalised world. Finally, the article proposes some new rules for a global environmental sociology and describes some of their possible implications for the sociological study of climate change.
\end{abstract}

\section{Corresponding author:}

Rolf Lidskog, Department of Sociology, Örebro University, Örebro, SE-70I 82, Sweden.

Email: rolf.lidskog@oru.se 


\section{Keywords}

Climate change, environmental sociology, globalisation, global sociology, public sociology

\section{Introduction: Globalisation, sociology and the environment}

Few would dispute the observation that globalisation is significantly changing the world. Although sociologists have different interpretations and definitions of what globalisation is, when it emerged as a major structuring force, and how to evaluate and assess its consequences in different sectors, fields and geographies, they agree that globalisation is one of the key developments that is (re)structuring the current phase of modernity. Globalisation is perceived through changing social practices, institutional developments and social controversies in different and sometimes unexpected and unwanted ways in distinct geographies, sectors and social fields.

Sociologists have also been reflexive in analysing, discussing and hypothesising what globalisation does and should mean for their own discipline. How does globalisation affect sociology in terms of organisation, themes, content and theory? Over the past decade and a half, if any topic has been especially prominent in the titles and subjects of the major and influential sociological publications, regardless of thematic, methodological or theoretical specialisation, it has been globalisation. Calls for a sociology of globalisation (e.g. Alamuti, 2013; Martell, 2010; Martin et al., 2006; Sassen, 2006) have been echoed by calls for a global sociology (Burawoy, 2009; Cohen and Kennedy, 2013), indicating the dynamic and reflexive nature of the discipline.

Globalisation has also affected the sociological study of interactions between society and the environment, a field often loosely labelled environmental sociology. However, a closer look at environmental sociology under increasingly globalised conditions reveals that a remarkable phenomenon has emerged within the field. Globalisation has to some extent resulted in an environmental sociology of globalisation that takes the form of sociological studies of how globalisation has affected the interactions between society and the environment. It has not, however, resulted in what could be called a global environmental sociology, one that is unified around the world in terms of the themes that are studied and the theories that are applied and developed - in short, one having a common epistemology and methodology. This can be seen most clearly when comparing the two regions where environmental sociology developed first and arguably has matured the most, the United States and Western Europe. Whereas a short decade ago Arthur Mol (2006) could still identify hopeful signs of mutual learning, exchange, convergence and integration in these two main regions' environmental sociologies, they currently seem to have drifted apart in terms of how they are being developed, defined, operationalised and institutionalised. In a world characterised by increasing interrelatedness and interconnectedness, where different cultures, governance structures, civic epistemologies and scientific systems and networks crisscross and mingle, the observation of a place-based divergence in sociological approaches to (global) environmental challenges seems an oxymoron. Starting from this observation, this article analyses current environmental sociologies and discusses the problems, prospects and outlooks 
of a future global environmental sociology. In doing so, we aim to extend the analysis beyond the 'old centres of the world'. Arguably, a truly global environmental sociology will be made as much in Asia and Latin America as in Europe and North America (or perhaps even more so).

There are several papers in the field of environmental sociology that compare and evaluate US and European sociological approaches to studying society-environment interactions, sometimes preferring and giving precedence to one of the positions, sometimes concluding that there is a need for synthetic approaches bridging the Atlantic, and sometimes celebrating the diversity of approaches as the way to move the discipline forward. In this article, we follow a different route, namely one of contextualisation. By placing the research approaches of both sides of the Atlantic in their different societal and historical contexts, the specific spatial distribution of the approaches is clarified, as well as their persistence in these times of globalisation and the (sometimes sharp) articulation of their differences.

One of sociology's hallmarks has always been its emphasis on context (Calhoun et al., 2007). The aim is not one of social reductionism, where everything - knowledge, institutions, practices - can be fully explained by and thus reduced to context. Rather, it is based on the idea that to sociologically understand a phenomenon, one must view it in relation to its context. By situating developments of different environmental sociologies in their contexts, we will be able not only to understand differences in environmental sociologies across the globe but also to say something about the type of demands an increasingly globalised context puts on environmental sociology. Phrased in the tradition of Durkheim, Giddens and Urry, what new rules are needed for environmental sociology?

The next section reviews the emergence of environmental sociology. Because the US and Europe played a central role in its early development, the third section traces the context-dependent differences in American and European environmental sociology, raising the question of the extent to which cross-Atlantic controversies and differences are hindering the development of a global environmental sociology. The fourth section widens the review of environmental sociology beyond Europe and the US, considering how some of the emerging national environmental sociologies define the subdiscipline. The final section focuses on the agenda for a global environmental sociology that is equipped to understand environment-society interactions in global modernity: the (un)sustainability of global capitalism, sustainable production and consumption, the emerging global network of environmental NGOs, and the shifting role of environmental authorities at different scales. For reasons of space, we necessarily focus on general or mainstream attributes of place-based environmental sociologies rather than on the individual environmental sociologists who deviate from it.

\section{Environmental sociology: Emergence and emancipation}

From the 1970s onwards a relatively small group of sociologists - first in the US and later in Europe and beyond - made significant efforts to bring environmental challenges into mainstream sociology, naming this subdiscipline environmental sociology. Since then, environmental sociology has been loosely defined as the sociological analysis and 
understanding of society-environment interactions. In the 1970s and 1980s environmental sociology fought an uphill battle with a rather hostile parent discipline that was unwilling to include environmental questions in its research programme (see the special issue of Organization and Environment in 2002, on the occasion of 25 years of US environmental sociology). However, over the last two decades environmental challenges have gained a prominent place in sociology. Global environmental change and globalisation have played major roles in this development.

The sociological analysis and understanding of society-environment interactions were strongly influenced by globalisation. Globalisation changed not only the content and understanding of sociological studies of environment and society but also the institutionalisation and centring of environment-society interdependencies in the wider sociological discipline in two ways. Sociological subfields that originally had no relation to environmental challenges became interested in environmental aspects, such as political sociology, urban sociology, organisational sociology, sociology of consumption, sociology of globalisation, sociology of social movements and feminist sociology. Second, general sociology increasingly moved into areas of (global) environmental change and had to ponder how and to what extent contemporary environmental challenges have implications for general social theory and sociological thought. Leading social theorists such as Ulrich Beck (1992, 2009), Niklas Luhmann (1989), Anthony Giddens (1990, 2009), George Ritzer (2001), Zygmunt Bauman (2004, 2011), Manuel Castells (2009), Bruno Latour (2004) and John Urry $(2011,2013)$ have contributed to how environmental problems, risks and reforms should be included in general sociology and sociological theory, sometimes referring to developments in the environmental sociology subdiscipline (e.g. Beck, 2009) and sometimes not (e.g. Giddens, 2009; Urry, 2013). This centring of environmental challenges in sociology was triggered by the emergence and rise of global environmental change on the (global) public and political agendas and by the influence of environmental change on most parts of society (and, thus, most fields of sociology). In this respect, globalisation affected environmental sociological themes and theories. However, this centring of the environment in the sociological discipline is also related to the fact that research councils have channelled significant funds to environmental areas, to which sociologists from different fields have responded by developing research on - or reframing existing research to include - environmental issues and discourses. Irrespective of the reason, the study of the environment has become fully institutionalised and mainstreamed in 21 st-century sociology, and globalisation has been part and parcel of this change.

As in many other subfields of sociology, environmental sociology involves different approaches, with their traditions, assumptions, methodologies, theories and key references. Perhaps more so than in other subfields, however, environmental sociology relates to, and crosses borders with a number of other disciplines and research areas that study environmental matters, such as political science, anthropology, psychology, development studies, environmental and human geography, human ecology, media studies, science and technology studies, interdisciplinary environmental studies and sometimes even economics and life sciences. This intensive cross-disciplinary activity further contributes to the diversity of approaches in environmental sociology. However, the existence of different approaches within environmental sociology is nothing special; this is 
the case for most sociological subfields. Debates within and between different approaches, traditions, theories and methodologies often stimulate progress in the discipline, set new research agendas and lead to innovations.

We believe that there is one remarkable observation and one question to be asked with respect to these differences in approach, methodology, assumptions and theoretical prevalence and preference in the field of environmental sociology. We observe that these different approaches in environmental sociology seem to come with a rather sharp spatial division, particularly between US environmental sociology and its European counterpart. The question, then, is as follows: What is happening to the spatial specificity of environmental sociology under conditions of globalisation and now that the subdiscipline has developed substantially in other regions, such as Asia and Latin America?

\section{Worlds apart? An identification and contextual explanation}

Any new subdiscipline (or discipline) needs to show that its knowledge claims are credible, both internally for its members and externally for the wider scientific community as well as society at large (cf. Jasanoff, 2011). This rarely happens smoothly; in most cases, the establishment of new knowledge areas is characterised by struggle. The presentation of new knowledge claims as credible and trustworthy is commonly accomplished by locating them within the sphere of authoritative knowledge, whereas other knowledge claims are assigned to a sphere of less authoritative knowledge or disregarded as nonknowledge or mere opinion (Gieryn, 1999). A new subdiscipline or research field needs a frame of reference that guides knowledge development within the field. It also needs an interpretative community - a group of researchers who share the mission of the new subdiscipline - to provide a fertile ground for collectively elaborating the field. To survive and develop as a subdiscipline, it is also important to develop a storyline and create an institutional space for internal debate. Due to their differing ambitions and contexts, US and European environmental sociologies institutionalised their fields differently, developed along different paths when it comes to legitimising their knowledge claims, and developed their core contents, theories and methodologies distinctively. ${ }^{1}$

In exploring and explaining these differences, we focus on how they use the sociological tradition, conceptualise the environment, organise and institutionalise the field, and are embedded in and relate to the non-academic context.

\section{Appropriation of the (classical) sociological tradition}

Since its origins, US environmental sociology has explicitly developed in relation to classical sociological thinkers, not least Marx, Weber and Durkheim. This is perhaps best exemplified by one of the first textbooks in environmental sociology, which has extensive sections relating each of these thinkers to environmental issues (Humphrey and Buttel, 1982; see also the fully revised Humphrey et al., 2002; and Sunderlin, 2003). Dunlap and Catton (1983; Catton and Dunlap, 1978) developed their version of environmental sociology in contrast to the legacy of classical sociology in contemporary sociology, particularly the Durkheimian tradition of social facts as the object of sociological study and the Weberian legacy of social definition of the situation (as developed by 
Mead, Cooley and Thomas). However, except for the massive criticism of Durkheim, US environmental sociology has devoted much space to demonstrating how its conceptualisation of environmental sociology is in line with classical sociological thinking (see e.g. Buttel, 2002a; Buttel and Humphrey, 2002; Foster, 2010; Pellow and Nyseth Brehm, 2013). In a similar celebration of the parent discipline, Dunlap (2002) emphasises that it is a common misinterpretation of his (and Catton's) work that classical sociology is irrelevant for environmental sociology; he only claimed that the legacy of these sociological traditions, as they had developed, led the discipline to ignore environmental factors and conditions.

Whereas Marx and Weber are highly appreciated (see the work of Allan Schnaiberg, James O'Connor and John Foster on (neo)Marxian environmental sociology and the work of Patrick West, [the Canadians] Raymond Murphy and John Hannigan, and John Foster on (neo)Weberian environmental sociology), criticism of Durkheim has been used to stage environmental sociology vis-a-vis general sociology. Many environmental sociologists have referred to Durkheim's methodological taboo against including biological variables in sociology, and Dunlap and Catton have mentioned this taboo in almost all of the articles they have published on environmental sociology. Recently, however, Rosa and Richter (2008) have stressed that Durkheim had a more complex understanding of social facts than environmental sociologists often admit, and they celebrate the explanatory role Durkheim accorded to population growth and its pressure on natural resources.

While there seems to be a shared belief in the importance of classical thinkers in sociology, far less widespread attention has been devoted to more recent work in US environmental sociology. Few studies discuss at any length the sociological theories from 1920 onwards, ${ }^{2}$ and references to contemporary general sociology - except for mentioning and often also criticising Ulrich Beck's seminal work Risk Society - are, in many cases, lacking (or at least are much less prevalent than in European studies).

In contrast, European environmental sociologists have put less effort into discussing and integrating classical sociology into their work, while strongly positioning their subdiscipline within the context of contemporary sociological thought (e.g. the textbooks of Yearly, 1991, 1996; Barry, 1999; Goldblatt, 1996; Gross and Heinrichs, 2010; Irwin, 2001; Martell, 1994; Redclift and Benton, 1994; Sutton, 2004). Of course, Europeans do refer to classical sociological thinkers, but few treat them as central for environmental sociology. (For an exception, see Gross [2000] who explores the importance of Durkheim and Simmel.) Instead, European environmental sociologists refer to and embed their studies more strongly in contemporary sociological theory, not least the contributions of Beck (1992), Bauman (2004), Giddens (1990), Luhmann (1989), Latour (2004), Sassen (2008), Urry (2011) and others who have explicitly written about current environmental challenges. However, European environmental sociologists also refer to and apply the work of contemporary sociologists who have focused less on environmental issues, such as Castells and Foucault.

Thus, the two regions have appropriated sociological traditions differently and legitimised environmental sociology in different ways. In the US, the contrasting of environmental sociology with 'mainstream sociology' created a need to demonstrate that environmental sociology is part of the sociological family, that is, to show that it is in line with fundamental sociological thought. ${ }^{3}$ Central to the justification of its sociological 
status was the need to prove and deepen environmental sociology's relation to classical sociology. This need was further strengthened by the ambition of US environmental sociology (especially the branch following Catton and Dunlap's HEP-NEP distinction) not only to create a subdiscipline but also to redirect the focus and agenda of general sociology. 4

In Europe, environmental sociology was never involved in major fundamental debate with general sociological thought, and it never had any ambition to fundamentally redirect general sociology. As a self-defined subdiscipline, environmental sociology really began to take off in the 1980s (see Mol, 2006), and major thinkers in general sociology began to discuss environmental issues soon after (e.g. Beck, 1992; Giddens, 1990; Luhmann, 1989). European environmental sociologists felt little need to contrast themselves with 'mainstream sociology' and to return to classical sociology to legitimise making room for environmental issues in sociology. It was believed that environmental sociology could learn from contemporary mainstream sociology in its development, and that contemporary mainstream sociology was not hostile to environmental issues at the birth of European environmental sociology. Hence, there were hardly any meta-theoretical or epistemological discussions in Europe.

The different legitimising strategies within the emerging subdiscipline also affected the configuration of the discussion within environmental sociology's epistemic community in the two regions. Even with a variety of approaches in US environmental sociology, the field is mainly framed as a distinct subdiscipline that is centred on key texts, core issues and leading founders. Dunlap and Catton's seminal works are accorded the status of classical texts, as most appositely expressed in William Freudenburg's (2008: 449) statement, 'In biology, of course, the pioneer was Charles Darwin himself. In environmental sociology the pioneers were Riley Dunlap and William Catton.' From that common and constantly shared origin and basis, differences emerge in US environmental sociology, but regular attempts also are made to realign these distinctive approaches by contrasting them with common 'threats' (mainstream sociology, ecological modernisation, Republican politics). In European environmental sociology it is difficult to find key persons or canonical texts with similar status, or core issues that gather environmental sociologists across Europe. The same holds for the national environmental sociologies in European countries. ${ }^{5}$ Instead, European environmental sociology is characterised by differentiation (and perhaps even theoretical fragmentation and eclecticism), which is sometimes legitimised by the value of diverse theoretical approaches and themes for moving forward. Arguably, two of the more coherent storylines within European environmental sociology over the years, the theory of Ecological Modernisation and Risk Society theory, never had the ambition of shaping a subdiscipline or meta-programme for environmental sociology.

\section{The conceptualisation of the environment}

US and European environmental sociology share a basic definition of the field: the study of human-environment interactions in modern society. They differ, however, in their conceptualisation of the environment, which implies different viewpoints concerning environmental sociology's relation to natural science. 
There is a coherent line of analysis, studies and thought in US environmental sociology that is centred on an understanding of the environment as partly constituted by biophysical realities. Starting with Catton and Dunlap's call to include biophysical variables in sociological analysis, it continues with the strong emphasis on absolute material limits (as coined in Catton's overshoot), the physical character of the landscape (Freudenburg et al., 1995), POET, STIRPAT ${ }^{6}$ and other models of Dietz, Rosa and colleagues, the metabolic rift (Foster, 1999) and a differentiated concept of nature involving ecological aspects (Carolan, 2005; McKinney, 2012). The claim they have in common is that environmental sociology needs to become more environmental in the sense of including in its analysis an understanding of social life as dependent on ecosystem processes (Carolan, 2005; Dunlap, 2008). This means that environmental sociology is 'dependent on' natural science's laws, calculations and materialities. Thus, knowledge about the physical state of the environment is deemed essential for environmental sociology. This approach has resulted in a US environmental sociology that is much more willing to include natural science parameters in its analyses while emphasising and protecting its disciplinary 'rigour'. ${ }^{7}$ Consequently, it also has resulted in less of a need and willingness for environmental sociology to enter into collaborative and crossand interdisciplinary endeavours with the natural sciences, though there are, of course, interesting examples of such cooperation.

European environmental sociology does not deny the importance of ecosystems for human societies, but it is much more reluctant to include material and ecosystem factors in its analyses (perhaps with the exception of contributions inspired by Latourian actor-network theory, which due to his criticism of the society/nature dichotomy includes materiality in a very different way than US environmental sociology; Latour, 1993). European environmental sociology does not doubt the existence of a biophysical reality, but what this reality is and what it means are always and only actualised through social practices and interpretative processes. As Macnaghten and Urry (1998: 250, italics in original) put it, 'We do not deny the enormously powerful effects that the physical world exerts and in particular its capacity to take massive and often deserved revenge upon human society. However, we are denying that there is an already formed and causally powerful set of environmental bads which in and of themselves can generate such havoc in the public realm.' Thus, European environmental sociologists tend to strongly define the environment sociologically by characterising it as consisting of mainly social processes (e.g. Irwin, 2001; Macnaghten and Urry, 1995) or, at best, as an intermediary domain between nature and society involving hybrid processes (e.g. Latour, 2004) or socio-material networks and flows (e.g. Spaargaren et al., 2006). Beck (1992) and Giddens (1990), as representatives of European sociology, claim that nature no longer exists outside society or society outside nature because nature has been fundamentally changed by human intervention, despite the fact that nature, to many, still appears to comprise a set of unbreakable rules that must be discovered, guarded and cultivated (Beck, 1995: 53). If anything, this view is more common among US human geographers than US environmental sociologists.

The hybrid character of the environmental issue does not, however, lead European environmental sociologists to conclude that biophysical variables or an ecosystem approach should take centre stage in environmental sociology. Instead, and in stark contrast with US environmental sociology, a major stream within European 
environmental sociology - drawing heavily on the sociology of science and science and technology studies - stresses the need for sociological analysis of the claims made by natural sciences and scientists (e.g. Irwin, 1995; Jasanoff, 2011; Wynne, 1996, 2001; Yearley, 1991). By being more self-reflexive, science can avoid taking part in risk production activities (Beck, 1992: 155). Thus, natural sciences and their representations should not be taken as neutral inputs into environmental sociology; instead, they should be critically and sociologically investigated by placing them in their social context, and possibly opened up for discussion of what we really know about the state of the environment. The result is that natural science arguments are rarely used authoritatively in European environmental sociology.

Disaster research provides a striking illustration of the difference in how nature is conceptualised and how much centrality it is given on either side of the Atlantic. Like any region, the US has experienced a number of environmental disasters, the most wellknown of which are the Santa Barbara oil spill (1969), Buffalo Creek (1972), Love Canal (1976), Three Mile Island (1979), the Exxon Valdez oil spill (1989), Hurricane Katrina (2005), Deep Water Horizon (2010) and Hurricane Sandy (2012). US environmental sociologists have conducted an impressive number of detailed studies of these and other catastrophes, studies which have also influenced the construction of environmental sociology (see e.g. Brunsma et al., 2007; Couch et al., 1999; Erikson, 1976; Freudenburg and Gramling, 1994, 2011; Freudenburg et al., 2012; Gunther and Kroll-Smith, 2007; KrollSmith and Couch, 1990; Picou et al., 1999). ${ }^{8}$ Europe has witnessed a similar series of environmental disasters, such as De Ramp (1953), Seveso (1976), Chernobyl (1986), Sandoz (1986), Aznacollar (1999), Erika (1999), Baia Mare (2000), Prestige (2002) and Ajka (2010). In Europe, however, few if any sociological studies exist on these catastrophes, and they have had little influence on the continent's environmental sociology. Beck (1992) has used the Chernobyl accident prominently in theorising about the coming risk society; Wynne (1996) draws on the radioactive fallout from Chernobyl to illustrate the contingency of expertise knowledge claims; and Dickens (2004) opens his book on society and nature by discussing a major storm. None of these authors has devoted a detailed, book-length study to these disasters, using them instead as illustrations of a general phenomenon for the sake of developing theory.

Environmental disasters provide a very specific foundation for developing environmental sociology; in environmental disasters, material conditions and consequences are clearly evident, and society's dependence on nature can readily be observed. For example, to understand the environmental disasters that Katrina produced, it is necessary to put New Orleans into its geographical context: the Mississippi Delta and human efforts to adapt to these natural conditions (e.g. cutting canals across the surface of the land, thereby rearranging the region's waterscape) (Brunsma et al., 2007, Kelman, 2003). In that sense, environmental disasters serve as a perfect example of what is meant by 'nature matters' and of why it is important not to exclude biophysical factors from sociological analysis.

These different conceptualisations of the environment lead some US environmental sociologists to interpret European environmental sociology as 'non-realist' due to its ignorance of biophysical aspects of reality, whereas European environmental sociologists view some of their US counterparts as unreflexive, as failing to see that all knowledge claims - including those produced by the natural sciences - are contingent, mediated 
and/or socially constructed. Whereas US environmental sociology claims that European environmental sociology brackets nature off, Europeans sometimes claim that US environmental sociology ignores the fact that environmental knowledge is socially constructed.

There is a further difference in how the environment is conceptualised in the two regions. US environmental sociology frequently focuses on environmental degradation, framing environmental protection as a question of survival and showing that modern society is on the wrong track. Despite technological innovations and institutional change, the environmental situation is becoming worse and political struggles and conflicts are increasing. Key concepts in US environmental sociology, such as the treadmill of production, the second contradiction of capitalism, environmental justice, environmentally unequal exchange and the Jevons paradox ${ }^{9}$ address this issue (e.g. Carolan, 2006; Foster, 2012; McLaughlin, 2012). Although European environmental sociology maintains a clear focus on environmental degradation (and even apocalyptic catastrophe; see Urry, 2011), it also concentrates on what it calls environmental reform. How decoupling is taking shape; what drives, organises and structures green technologies; how to understand the involvement of economic actors and institutions in environmental reform trajectories; and how to theorise major civil society organisations becoming 'private governance actors' are all typical questions that prevail in European environmental sociology but not (or less so) in the US. This difference is also reflected in theories of ecological modernisation and of transition, which are less prevalent in the US. The late Fred Buttel (2003) noted a decade ago that the sociology of environmental reform is largely absent in the US, and this observation still holds today.

\section{Organising environmental sociology as tradition}

US environmental sociology is highly institutionalised. Buttel (2002b: 44) and Mol (2006) note that the stature of environmental sociology is more an issue for US environmental sociologists than for sociologists in other developed countries. In 1973, the Environmental Problems Division within the US Society for the Study of Social Problems was founded. The division functioned as an institutional base for sociologists conducting environmental research. In 1976, a section on Environmental Sociology was established within the American Sociological Association (ASA). (In 1986, it was renamed the Environment and Technology Section.) Since that time, this section has been pivotal for the development of US environmental sociology. Representing a new field of study that attracted many sociologists early in their careers, the section provided an important space and (digital) platform for developing and exchanging research and for building a shared identity, as well as being a home for environmental sociologists scattered throughout a large country with many universities, each often housing only one or a few environmental sociologists. The section has been successful in terms of membership, socialising new young scientists, creating a self-identity and maintaining and developing environmental sociology as a subdiscipline. In reflecting on the history of US environmental sociology, Dunlap finds that being a 'small oppressed minority' in US sociology was functional for its constitution, group identity and development (Tàbara and Polo, 2006: 177). This frame of smallness - being a minority in a hostile outside world (scientifically, politically and theoretically) - has continued over the years. A common group identity with strong 
boundaries implies, for instance, that Europeans, with their more eclectic, less politically correct and more socially constructivist identities, did not always feel welcomed.

European environmental sociology is much less institutionalised, more pluralistic, and a much weaker provider of identity. This is partly because Europe is a continent constituted by a large number of nation-states. The European Sociological Association (ESA) is a rather new organisation (founded in 1995) consisting of 33 national member organisations. Several of these national associations have environmental sections, of which the German Sektion Umweltsoziologie is arguably the strongest and best organised. This makes the ESA's research network on Environment and Society much smaller and gives it a less directing role in the development and socialisation of environmental sociologists than the environmental section of the ASA. However, the more pluralistic character of European environmental sociology is also due to the less fractionalised character of sociology in Europe. The environmental sections of both national and European sociological associations do not have the mission of building a subdiscipline, forming a group identity or redirecting general sociology. Hence, European environmental sociologists have not developed a shared identity or epistemological core. Instead, members of the ESA's Environment and Society section may have a much broader (inter)disciplinary background, such as in social movement studies, political sociology, science and technology studies, public administration or global studies, but not a common identity. European environmental sociologists engage in easy and frequent boundary crossing with other disciplines - joining networks, publishing in journals, collaborating on projects and applying concepts and approaches. In the national and European environmental sociology networks, we are witnessing a community and identity formed around environmental social sciences rather than environmental sociology.

\section{The non-academic context}

Since its birth in the early 1970s, American environmental sociology has combined a strong academic profile with political critique, clear political positions and strong political engagement. Part of the motivation for early environmental sociologists to enter this field rather than another sociological subdiscipline involved the degradation of the environment (as can be read in the narrative histories of the founding fathers: Buttel, 2002b; Dunlap, 2002; Schnaiberg, 2002). This situation was similar in Europe. However, political commitments and preferences have been expressed quite differently on the two continents, especially when it comes to their incorporation into academic work. A major part of US environmental sociology, well represented in King and McCarthy's (2009) environmental sociology reader, seems to be politically committed, and certain strands (e.g. environmental justice scholars) are strongly engaged with grassroots-level initiatives, non-elite (minority, native American) groups, non-Washington DC based environmental NGOs, and local communities and networks (e.g. on organic food). ${ }^{10}$ Such political positions and commitments are quite consequential; not merely incidentally, they 'allow' environmental sociologists to step outside of their ordinary sociological research and use natural science facts, demography and the like to close sociological debates on the environment. For a European environmental sociologist, attending sessions at the ASA Environment and Technology section and following debates on the section's (very informative) listserv is sometimes an alien experience. 
US academic environmental sociology forms a type of 'counter-hegemonic' discipline that is strongly linked to grassroots social movements and that is not significantly engaged with federal policy-makers, major companies and major non-governmental and international organisations. The gap in the US between environmental sociologists and the environmental state (especially at the federal level, but also at the state level) seems to have especially widened under the Bush administration. Even if there has been some change under the Obama administration, there is still a gap tied to the highly polarised Republican-Democrat landscape that runs through an increasing number of fields in American society, including sociology.

Although some political commitment and motivation were certainly also evident in European environmental sociology in the 1970s and 1980s, this situation is less naturally prevalent in post-1990 Europe. Whereas European environmental sociology has certainly not turned its (politically engaged) face away from, for instance, environmental NGOs, local communities and the anti- or other-globalisation movements, studies on the environmental reforms of multinationals, regulatory reform in national and supranational environmental bureaucracies and appreciation for and engagement with new private arrangements between multinationals and NGOs (although to differing extents in different European countries) show the diversification of political engagement, positions and preferences in mainland Europe. Political engagement in European environmental sociology is no longer automatically critical of the state and economic growth, or supportive of grassroots activism. This is because of developments among environmental advocates within society, perhaps best illustrated by the institutionalisation and 'mainstreaming' of the German Greens, who have developed from a radical activist network of local green groups (see Huber, 1982) into a significant national institutionalised political force and architect of Germany's renewable energy policy. In addition, European environmental sociology has developed a more 'reflexive bias' (Lange, 2002), following a stronger institutionalisation of environmental NGOs and green parties in the arenas of power. European environmental sociology seems to have a significantly higher degree of science-user interactions than its US counterpart, with environmental sociologists more often working closely together with various (also hegemonic) user categories, sometimes in applied ways. In the US context, one might find this type of user interaction in social science research to be less common within (environmental) sociology than in other disciplines, such as public and business administration studies and organisation studies.

These differences in non-academic contexts are not the monopoly of environmental sociology but are also experienced in other fields of sociology. The call for a 'public sociology' at the 2004 ASA conference was interpreted especially as calling on sociology to resist the perceived dominance of neoliberalism in the US and of US (political and economic) hegemonic forces. Sociology should take sides and cannot be an independent interpreter standing on the sideline while major social inequalities exist and environmental disasters unfold. In Europe, such calls for a public sociology have not emerged as forcefully.

\section{Summary}

Since its beginning, US environmental sociology has been devoted to developing a metatheoretical foundation centred on the claim that biophysical factors should be given a 
place in sociological analysis. It has created a coherent storyline where key persons and key texts, historical events (not least environmental disasters and social protests) and key achievements are interwoven. Moreover, it has developed in the frame of a hostile environment of the parent discipline, the political mainstream and state and economic power centres. The history of the origin and development of environmental sociology is a story that is repeatedly told and is part of the collective legacy of the field. The result is a shared identity and an epistemological core that provides both opportunities for knowledge development and a need to defend it against competing and conflicting views.

European environmental sociology has not formed a strong, let alone unifying storyline. There is no canonisation of key texts, celebration of founding scholars, or common identity formation. Furthermore, even if important environmental events have occurred in Europe (the achievements of social movements, environmental disasters), they have not been researched by environmental sociologists to any greater extent than by other disciplines and have not been used to support the development of a European environmental sociology. The result is a rather eclectic environmental sociology with stronger boundaries towards the natural sciences but with fewer boundaries towards other social sciences and much closer interaction with a diversity of user categories.

These differences are summarised in Table 1.

Table I. Key differences between US and European environmental sociology.

\begin{tabular}{|c|c|c|}
\hline & US & Europe \\
\hline $\begin{array}{l}\text { Use of the } \\
\text { sociological tradition }\end{array}$ & $\begin{array}{l}\text { Builds more on the classical } \\
\text { sociological thinkers (Marx, } \\
\text { Weber). }\end{array}$ & $\begin{array}{l}\text { Relates more to contemporary } \\
\text { sociological theory (Beck, } \\
\text { Giddens, Latour, Urry). }\end{array}$ \\
\hline \multirow[t]{2}{*}{$\begin{array}{l}\text { Conceptualisation of } \\
\text { the environment }\end{array}$} & $\begin{array}{l}\text { Natural science parameters } \\
\text { serve as input in sociological } \\
\text { analyses; the environment } \\
\text { is seen as partly constituted } \\
\text { by biophysical realities } \\
\text { independent of social } \\
\text { practices. }\end{array}$ & $\begin{array}{l}\text { Biophysical reality is seen } \\
\text { as real but always and only } \\
\text { actualised through social } \\
\text { practices and interpretative } \\
\text { processes. }\end{array}$ \\
\hline & $\begin{array}{l}\text { - Focus is on explaining } \\
\text { environmental degradation. }\end{array}$ & $\begin{array}{l}\text { - Focus is also on explaining } \\
\text { environmental reform. }\end{array}$ \\
\hline $\begin{array}{l}\text { Organisation and } \\
\text { institutionalisation of } \\
\text { the field }\end{array}$ & $\begin{array}{l}\text { Environmental sociology is highly } \\
\text { institutionalised at national level } \\
\text { with a shared identity and an } \\
\text { epistemological core. }\end{array}$ & $\begin{array}{l}\text { Environmental sociology is much } \\
\text { less institutionalised at national } \\
\text { and continental level, is highly } \\
\text { pluralistic, and is a weak provider } \\
\text { of identity. }\end{array}$ \\
\hline $\begin{array}{l}\text { Relations with } \\
\text { the non-academic } \\
\text { context }\end{array}$ & $\begin{array}{l}\text { Combines a strong academic } \\
\text { profile with a 'counter- } \\
\text { hegemonic' outlook that is } \\
\text { strongly linked to grassroots } \\
\text { social movements. No significant } \\
\text { engagement with formal political } \\
\text { institutions, private corporations } \\
\text { or large NGOs. }\end{array}$ & $\begin{array}{l}\text { A considerable degree } \\
\text { of interaction between } \\
\text { environmental social scientists } \\
\text { and users, sometimes in applied } \\
\text { ways. User groups include formal } \\
\text { political institutions, private } \\
\text { corporations or community-based } \\
\text { organisations and NGOs. }\end{array}$ \\
\hline
\end{tabular}


Our point is that different contexts provide different opportunities, limitations and paths for the development of (sub)disciplines. Hence, the different trajectories of US and European environmental sociology are explained by their different contexts. These differences are not without consequences, however. Although there have been connections and collaborations between environmental sociologists from the two regions, as well as notable efforts to downplay the differences, build bridges and achieve cross-fertilisation between the two regions (see e.g. Buttel, 2000; Cohen, 1999; Goldman and Schurman, 2000; Lidskog, 2001; Mol, 2006; Mol and Spaargaren, 2005; Redclift, 2009), strong dynamics are also at work that separate these regional traditions and articulate distinctions. There also seem to be misunderstandings and some risk of mutual disapproval between environmental sociologists on either side of the Atlantic. Recently, for instance, a number of US scholars have claimed that environmental sociology today faces a double challenge: to combat the current environmental threats and to confront those versions of environmental sociology that have incorrectly conceptualised the field (e.g. Foster, 2012; McLaughlin, 2012).

What happens when globalisation processes increasingly permeate spatial contexts and when environmental sociology matures in other spatial contexts? This question is discussed in the next two sections.

\section{'New world' environmental sociology}

Environmental sociology has never been limited to the US and Europe; it has also grown and developed in many other parts of the world. In addition to Australia, New Zealand and Canada, we can find major developments within and institutionalisation of environmental sociology in Asia, including Japan, South Korea, India and China; in Latin America, including Brazil, Chile and Argentina; and in some African countries, such as South Africa. Within the framework of this article, it is impossible to present a similar analysis for these regions as the one we have conducted for the US and Europe. By elaborating on only a few countries in East Asia (Japan, South Korea, China) and Latin America (Brazil), we aim to illustrate how national environmental sociologies have developed in the distinct contexts of the 'new world', both building upon and deviating from the environmental sociology traditions of the 'old world'.

\section{East Asia}

In Japan, environmental sociology originates from and is still related to concern for the victims of environmental pollution - from the Minamata case in the 1960s (Funabashi, 2006; Iijima, 1993, 1994; Iijima et al., 2001; JAES, 2006) to the Fukushima nuclear incident of 2011 (Funabashi, 2012) - and to the study of (environmental) social movements and local politics from the 1960s and 1970s (Miyauchi, 2006; Nakazawa, 2006) until today. Japanese environmental sociology understands itself as the sociology of environmental problems with a focus on local communities and on the lives of people affected by environmental problems, in addition to environmental policy and the decision-making process. It has a strong tradition of empirical research, mainly taking the form of case studies on such things as the Fukushima disaster (Hasegawa, 2012), 
local environmental movements (Broadbent, 1998; Hasegawa et al., 2007) and (in)formal institutions that manage commons at the local level (Miyauchi, 2006). Japanese environmental sociology - not unlike its parent discipline - is less theoretically engaged than European or US environmental sociology (for an exception, see the work of Funabashi, 2011).

With the establishment of the Japanese Association for Environmental Sociology (JAES) in 1992, Japanese environmental sociology became strongly institutionalised. JAES has more members than its US and European counterparts (600 members in 2013) and even has its own 'Journal of Environmental Sociology'. It shares with US environmental sociology a focus on and identification with grassroots NGOs and protests, limited interactions between science and (mainstream) users and an agreed-upon founder (Nobuko Iijima). However, it has weaker disciplinary boundaries and a weaker group identity than US environmental sociology, with frequent disciplinary boundary crossings with the wider social sciences, not unlike Europe.

In a similar way to Japan - though later - South Korean environmental sociology began in the 1980s due to concerns about pollution, its victims and local environmental protests. A rich body of literature has emerged with case studies and wider surveys of local pollution and the destruction of nature and the engagement of local and national protest movements $(\mathrm{Ku}, 2011)$. Environmental and pro-democracy movements collaborated closely in Korea in the 1980s, which is reflected in studies in South Korean environmental sociology. In the 1990s, the subdiscipline broadened to address wider environmental issues. For a long time, the debate was dominated by the question whether, in such a rapidly developing country, it was possible to avoid trade-offs between development and the environment (Moon and Lim, 2003). This debate fitted into the more general modernisation debates within Korean sociology, which were initially characterised by the perspective of conventional modernisation but became increasingly critical of its socio-political and environmental consequences. The 'indigenisation' of Korean sociology became a central issue, related to debates on a specifically Korean variety of modernisation (Myoung-Kyu and Kyung-Sup, 1999).

Over time, environmental sociology has to some extent become institutionalised in South Korea. It has been taught at universities since the early 1990s, and a Research Group on Environmental Sociology was established in 1995 followed by the founding of the Korean Association for Environmental Sociology in 2000 (Lee and Park, 2002). However, Korean environmental sociologists, not unlike those in many European countries, are not clearly recognisable as a group with a common identity and a strong disciplinary orientation. Compared to Japan, the Korean Association does not function as a platform for bringing environmental sociology scholars together. However, it does share its prevailing thematic orientations (victims, protests, NGOs, local pollution and local politics).

General sociology has a relatively short history in China,${ }^{11}$ and environmental sociology developed rather harmoniously within the parent discipline, albeit somewhat late. In the mid-1990s, when the environmental situation in the country further deteriorated due to the rapid economic development (Maohong, 2004), environmental sociology found its way into the academic curriculum and research, hitherto mainly in textbooks and publications written in Chinese (Hong and Xiao, 2007). Because Chinese sociology, 
according to Hong and Xiao (2007: 2), 'always paid close attention to the influences of environmental factors on social structures and changes', it did not feel the need to contrast itself with the parent discipline in emancipatory US-style. Chinese environmental sociologists share with their parent discipline a focus on empirical research as well as weak engagement with general sociological (classical or modern) theory but stronger engagement with environmental sociology scholars and theories from the 'old world' (some of which were translated into Chinese).

Compared to the other two Asian countries, environmental sociology in China is at an early stage of development, organisationally and substantially. The specifics of the country's system mean that the prevailing studies are less focused on victims, local protests and NGOs than in Japan and Korea (although this has recently begun to change), and concentrate instead on environmental perceptions and attitudes as well as policies and governance (failures). Chinese environmental sociology is dominated by a 'development' frame, according to which China is rapidly and deeply transforming economically and socially but is not improving environmentally. Hence, Chinese environmental sociologists empirically study the social causes of environmental deterioration through local case studies (e.g. Lin et al., 2009), and/or surveys (e.g. Xiao and Hong, 2012; Xiao et al., 2012). Environmental sociology in China shares with its European counterpart a greater orientation towards 'feasible solutions' than radical system criticism, but it differs with regard to its limited theoretical engagement, despite recent engagements with modernisation theories (He, 2012).

In all three Asian countries, major international environmental sociology conferences (Kyoto 2001; Seoul 2004; Beijing 2007) have been important for national subdisciplinary development and global visibility and integration. A regional East Asia network was developed (Asia-Pacific Connection for Environmental Sociologists, APECS) with regular regional environmental sociology/social science conferences. Nevertheless, the majority of publications in these countries are in the national languages, limiting the global appreciation and integration of these national environmental sociologies.

\section{Brazil}

Much more than in Asia, and in line with Brazilian general sociology, environmental sociology in Brazil has always relied on, engaged with and aimed to contribute to sociological theory (mostly contemporary, but also classical). A broad range of theoreticalmethodological perspectives from contemporary sociologists such as Beck, Giddens, Habermas, Latour and Castells have been applied in environmental sociology, sometimes only after translation of their work into Portuguese. Brazilian environmental sociology, which became well established in the 1990s, uses and contributes to environmental sociology frames such as constructivism, ecological modernisation, risk society, political ecology and neo-Marxism (Da Costa Ferreira et al., 2006).

Empirically, the focus has been on environmental politics and environmental movements, with particular attention being given to 'the specificity of socio-environmental problems in developing countries' (Da Costa Ferreira, 2002: 14), the Amazon and food and agriculture. Brazilian environmental sociology is 'definitely breaking with the 
hypothesis defending that the causes of resource exhaustion fall exclusively upon population growth'. Hence, the search for alternatives 'resides in finding means to avoid the scarcity and exhaustion of natural resources' (Da Costa Ferreira et al., 2006: 13). Thus, Brazilian environmental sociology goes beyond an exclusive focus on the destruction of the Amazon forest and includes urban environment issues, (food) risk and broader relationships between development and nature. Although the research emphasis is still strongly on domestic Brazilian developments, it has more of a global focus than Asian environmental sociology, in terms of both including globalisation among the themes that are studied and sourcing (environmental) sociology approaches, theories and scholars from around the globe.

The national association ANPPAS (Associação Nacional de Pós-Graduação e Pesquisa em Ambiente e Sociedade), established in 2000, is the organisational framework for Brazilian environmental social scientists (including sociologists), with a large biannual conference and a scientific journal Revista Ambiente e Sociedade (also published in English since 2013). Environmental sociology is well established in various university postgraduate and research programmes around the country and has strong international connections.

\section{Transgressing divides: Building a global environmental sociology}

Environmental sociology has moved beyond the regions where it emerged, the US and Europe. The analyses of East Asia and Brazil (and we could add many more countries and regions) illustrate that environmental sociology has diffused around the world since its birth in the 1970s, although it has not yet matured and been institutionalised equally in all countries. The spatial distribution of the constituency of the Environment and Society research committee of the International Sociological Association serves to illustrate both the globalisation of environmental sociology and its unequal proliferation in different countries/regions. ${ }^{12}$ In addition to this diffusion to different countries and regions, there are various handbooks that include different perspectives, approaches, themes and authors from distinct regions (e.g. Dunlap and Michelson, 2002; Gross and Heinrichs, 2010; Lockie et al., 2013; Redclift and Woodgate, 2005, 2010) and textbooks with global reach (e.g. Bell, 2012; Gould and Lewis, 2009; Hannigan, 2006; King and McCarthy, 2009; White, 2004; Yearley, 2009), and a global journal for environmental sociology (Environmental Sociology, launched in 2015).

At the same time, our investigation into the similarities and differences between the versions of environmental sociology in a number of countries and regions shows that their contents, perspectives and organisational forms are influenced heavily by their national and regional contexts and legacies but only marginally by the tendencies and processes of globalisation. In this sense, one should speak of multiple place-based environmental sociologies, which are connected but only moderately integrated, rather than one global environmental sociology. For instance, Pellow and Nyseth Brehm's (2013) otherwise very informative agenda for 21st-century environmental sociology only relies on US environmental sociology literature, frames and issues, and many of 
the recent environmental sociology handbooks lack 'new world' authors (and thus their priorities, framings and approaches). This is quite remarkable in these times of globalisation.

To be sure, there is nothing wrong or undesirable about having multiple themes, multiple theories, different approaches and various organisations in environmental sociology (or any other subdiscipline, for that matter). However, in a globalised world one would neither expect nor desire that such multiplicities and differences would be placebased and drawn around political borders of nation-states or regions. One would rather expect that environmental sociology clusters would gather around theoretical, methodological or thematic areas (such as 'schools-of-thought' or themes like climate change), each populated by sociologists from different parts of the world who frequently interact and build a common frame of reference and knowledge. This would constitute a global environmental sociology, one well-suited to study global interconnections, interdependencies and (unequal) distributions (of capital, trade and investments, information and media, [protest] movements, ideas and discourses, pollution and biodiversity) as well as how these subjects function or are addressed differently in specific social and environmental places.

Of course, we can already see the beginnings of a global environmental sociology addressing global themes such as climate change, global environmental institutions and global environmental movements. However, global environmental sociology is more than just a sociological study of global environmental problems, global protests or global policy arrangements. It also needs to consider local/national specificities, because environmental problems must always be contextualised to be explainable. Hence, a global environmental sociology must be sensitive to local context, yet at the same time reflect upon, question and criticise approaches, theories and frames that are specific to or prevalent in only one context. Only then can we (a) prevent the development of poorly connected/integrated place-based environmental sociology communities and (b) allow for much more cross-fertilisation between different traditions, frames and approaches in environmental sociology.

\section{Rules for a global environmental sociology}

With no claim to completeness, we provide below a preliminary sketch of what we would label 'rules for a global environmental sociology'. In the end, of course, such a list of rules can only be formulated and completed by a multitude of (environmental sociology) voices from different clusters (be they regional, theoretical or thematic). At this stage, the urgency of creating such rules is as important to us as the rules themselves. The aim of constructing and discussing an agenda for 'rules for a global environmental sociology' is to prevent the emergence of isolated, inward-looking, place-based environmental sociologies that condemn or neglect other environmental sociology islands. In our view, the rules for a global environmental sociology include the following:

- A global environmental sociology analyses local and place-based environmental issues (such as local protests, local pollution victims, local governance) while maintaining an understanding of their global embeddedness and co-construction. 
Similarly, a global environmental sociology will understand global environmental issues (such as global governance arrangements/regimes, global trade, global environmental movements) only by including (different and distinct) place-based and contextual specificities, practices and effects in the analysis. To use Castells' (2009) terminology, ultimately, neither place-less nor flow-less sociological analyses work in a globalised world.

- A global environmental sociology is aware of and acknowledges different national/ regional research traditions and approaches. However, instead of condemning, celebrating or defending them, it attempts to understand and explain their contextual emergence, reflects on whether and how these contexts influence research, and explores how these national/regional approaches can fruitfully contribute to cross-boundary sharing of and learning from findings and concepts. In doing so, global environmental sociology contributes to a cosmopolitan perspective (Beck, 2009) in general sociology.

- Although environmental sociology has specific objects of thought and reflection (society-environment interactions), the work of investigating and explaining these is always related to general sociology. As Redclift (2000: 161) argues, 'the problem of globalization and the environment brings us back to the origins of social theory'. Hence, a global environmental sociology builds on, is anchored in and contributes to the wider discipline of sociology.

- A global environmental sociology acknowledges that studies (under conditions) of globalisation involve the blurring of disciplinary boundaries, and thus it makes use of, welcomes and profits from the mixing and in-migration of concepts and approaches from other social science disciplines. Collaboration with natural scientists may contribute to innovative conceptualisation if social dynamics are treated as seriously as environmental dynamics. Disciplinary collaboration and the in-migration of disciplines should not result in the dissolution of the sociological discipline, although it might become increasingly more difficult to distinguish sociology from some of the other social sciences.

- A global environmental sociology should and will have expanding global institutions: global research networks, global journals, global conferences, global platforms for debate and exchange, global signs of recognition, global funding schemes and global audiences. These expanding global research institutions should not replace their national counterparts but instead complement them, and have to be recognised by these national counterparts.

- Environmental sociology has always been motivated by concern for environmental problems and solidarity with victims of pollution and resource extraction, and it aims to mitigate and address these devastations. Global environmental sociology is not just a critical sociology of environmental problems, nor just a solution-oriented sociology of environmental reform. It is not just ivory-tower environmental sociology, nor just applied environmental engagement. It is not just the politically correct strategic use of scientific authority, nor is it uncommitted scientific eclecticism. A global environmental sociology is a critical-constructive public sociology (cf. Burawoy, 2009) that engages academically with different disciplines and with non-academic constituencies without abandoning its reflexive and disciplinary character. 


\section{What does it mean? The sociology of climate change as an example}

Using the example of sociological research on climate change, we wish to illustrate where and how these new rules for global environmental sociology would change current research practices.

Climate change has reached top priority on global political and research agendas, and many nation-states, environmental movements, international organisations and scientific communities are calling for immediate and concerted action. In response, various kinds of natural and environmental scientists have dramatically changed their research agendas, however whether or not our discipline has fallen short on this account remains open to debate. Lever-Tracy (2008a) and other sociologists debating climate change in a 2008 symposium in Current Sociology ${ }^{13}$ claim that, to some extent in line with discussions during the establishment of environmental sociology in the US in the mid-1970s, the sociological discipline has largely ignored climate change, despite the fact that the rate of change in natural processes will have revolutionary implications for society and social processes. For at least two reasons we believe that this symposium does not reflect a global environmental sociology. First, the symposium discussed sociological interpretations of climate change in a very restricted way, perhaps because the contributions only came from the US and Australia. A second and related reason is that while the claimed absence of sociologists in climate change research might largely be true for the US around 2008, European mainstream sociology had by then fully incorporated climate change into its research agenda.

A study of climate change according to the rules for a global environmental sociology would imply a sociological framing of the climate issue following the above rules. Here is not the place for a full-fledged systematic interpretation of climate change; instead we will indicate some possible implications of a global environmental sociology for future research. Even if the world has always been global, it has never been as globalised as today; almost all places, practices and activities are connected to others. This means that strict borders and boundaries, such as between states, cultures, markets and communities, are being eroded. Hence, climate change is a challenge that transcends existing boundaries and categories. In addition, we will stress three further implications of this for sociological analyses of climate change.

The first implication is that the still dominant sociological approach of 'methodological nationalism' (where the nation-state is the primary unit of sociological investigation) needs to be replaced by a 'methodological cosmopolitanism', where analysis of society is not defined, organised and limited by the nation-state (Beck et al., 2013). Instead, a global environmental sociology stresses that even if the nation-state is a central actor in climate change negotiations and national rule-making, understanding climate change mitigation requires going outside this nation-state container. New transnational constellations of actors are arising from the challenges that climate change poses. What we have is a patchwork of partly overlapping assemblies, responding to various kinds of demands at different levels and in different sectors. Obviously, this does not preclude the study of international organisations, nation-states or local communities, but only means that these have to be studied as being co-constructed and socially embedded in wider assemblages. It is in the ties of global networks and the flows with local actors and places that climate change is to be analysed and understood. 
A second implication is that the border commonly drawn between society and nature needs to be transcended. In reality, there are no such things as 'normal weather' or 'natural climate change'; it is impossible to find a distinct human-induced climate (Hulme, 2010). What exists is a hybrid, where human and non-human 'agents' (e.g. sun, volcanoes, oceans) co-produce our climate. Thus, we live in a hybrid system where the climate is co-produced by nature and society. While it is rather common to separate nature and society, resulting in, for example, claims about limits and planetary boundaries and the need for humanity to operate within them (see e.g. Rockström et al., 2009), global environmental sociology argues that these boundaries need to be contextualised and historicised. For example, much research on climate change today uses linear thinking based on projected environmental and social damage caused by biophysical changes arising from greenhouse gases. By putting society at the centre instead, it can be shown that it is not increased biophysical change per se that poses a risk to local communities, but the dynamics between a changing climate and place-specific characteristics of particular communities. Thus, climate change should not be reduced to a change in nature to which society has to respond, but must instead be seen in terms of society/nature dynamics. This is a problem possessing both social and environmental characteristics, rather than an abstract scientific problem that can be disarticulated from and placed outside of social processes. Stressing the society/nature dynamics implies that sociology should not take changes in nature as the starting point for its analysis of climate change, but instead focus on how climate change is co-constituted by the dynamic interactions between social and natural processes.

A third implication is that climate change challenges the borders within sociology (between different sociological theories and interpretation schemes) as well as between sociology and other disciplines. A global environmental sociology should not take a specific framing of the climate change issue for granted, such as that of the Intergovernmental Panel on Climate Change (Beck et al., 2014; Van der Sluijs et al., 2010; Wynne, 2010). Nor should it give precedence to sociological interpretations over those of other disciplines. Other disciplinary understandings of climate change should be welcomed and allowed to enrich sociological framings, but not uncritically imported as neutral inputs to the sociological analysis. Thus, by collaborating with different contexts and interpretations (regional as well as disciplinary), a global environmental sociology should be better equipped to investigate and understand the different meanings, contestations and challenges that climate change issues imply for different actors - be they negotiators, industrial representatives, stakeholders or citizens - but also for the discipline itself. In that sense, a global environmental sociology is reflexive but remains environmentally and socially engaged at the same time, so as not to turn into eclecticism or ivory-tower science.

\section{Acknowledgements}

We thank David A Sonnenfeld (State University of New York), Gert Spaargaren (Wageningen University) and three anonymous reviewers for their constructive comments on earlier versions of the manuscript. Responsibility for the arguments made in the article remains, however, with the authors alone. 


\section{Funding}

This research received no specific grant from any funding agency in the public, commercial, or not-for-profit sectors.

\section{Notes}

1. Differences are sometimes expressed in debates, such as between US neo-Marxist environmental sociologists and European ecological modernisation scholars (cf. Foster, 2012; McLaughlin, 2012; Mol and Buttel, 2002).

2. For some exceptions, see Brewster and Bell (2010), who discuss Goffman; Bell (2012), who includes many of the modern sociologists and their relevance to environmental questions; and Szasz (2009), who draws strongly on contemporary sociological theory.

3. This need was also perceived because US environmental sociologists were often based in rural sociology programmes and land grant universities outside the main sociology departments and programmes at 'liberal arts' and 'arts and sciences' colleges.

4. Catton and Dunlap (1978) argued for the need to replace the dominant western worldview (the Human Exemptionalism Paradigm, HEP), according to which human beings and society are seen as independent of their ecological surroundings, with the New Ecological Paradigm (NEP), which stresses that humans are dependent on ecosystems. According to them, this means that sociology also needs to take biophysical and environmental issues into account in its analysis.

5. Of course, some individual sociologists celebrate particular founders; see, for instance, Studholme (2007), who claims Patrick Geddens to be the founder of UK environmental sociology.

6. POET stands for Population, Organisation, Environment and Technology and STIRPAT for Stochastic Impacts by Regression on Population, Affluence and Technology. Both models focus on the dynamic couplings between human systems and the ecosystems upon which they depend.

7. This followed a strong influence of structuralist human ecology, demography and Parsonian functionalism in US environmental sociology, which later was reinforced by functionalist socio-ecological modelling.

8. Ray Murphy's (2009) impressive research on the ice storm disaster that hit northeast Canada and the US can be interpreted in the same tradition.

9. The Jevons paradox (described by the British economist WS Jevons in 1865) means that increased efficiency in resource use will not lead to decreased environmental effects but the opposite. The reason for this is that improved technological efficiency will result in lowering the costs of using a resource and thereby making possible increased consumption of it (or other resources). Closely related to this paradox is the current discussion on the rebound effect, which states that increased efficiency implies a decrease in price of a resource which increases demand for the resource.

10. Of course, there are exceptions, such as those strands that have teamed up with the American Association for the Advancement of Science and the National Research Council.

11. General sociology actually re-emerged in China only in the 1970s after a 26-year ban (Hong and Xiao, 2007).

12. Membership in ISA RC24 is particularly strong in Europe, North America, Australia and New Zealand, as well as in East Asia, is growing in Latin America, but is weak in Africa, Southeast, Central and Western Asia, and in the CIS states.

13. The issue included contributions from Lever-Tracy (2008a), Brechin (2008), Leahy (2008) and Lever-Tracy (2008b). Later, Grundmann and Stehr (2010) also responded to Lever Tracy's article. 


\section{References}

Alamuti MM (2013) Critical Rationalism and Globalisation: Towards the Sociology of the Open Global Society. London: Routledge.

Barry J (1999) Environment and Social Theory. New York: Routledge.

Bauman Z (2004) Wasted Lives: Modernity and its Outcasts. Cambridge: Polity.

Bauman Z (2011) Collateral Damage: Social Inequalities in a Global Age. Cambridge: Polity.

Beck S, Borie M, Esguerra A et al. (2014) Towards a reflexive turn in the governance of global environmental expertise. The cases of the IPCC and the IPBES. GAIA - Ecological Perspectives for Science and Society 23(2): 80-87.

Beck U (1992) Risk society: Towards a New Modernity. London: Sage (originally published 1986).

Beck U (1995) Ecological Politics in an Age of Risk. Cambridge: Polity.

Beck U (2009) World at Risk. Cambridge: Polity.

Beck U, Blok A, Tyfield D and Zhang JY (2013) Cosmopolitan communities of climate risk: Conceptual and empirical suggestions for a new research agenda. Global Networks 13(1): $1-21$.

Bell M (2012) An Invitation to Environmental Sociology, 4th edn. Thousand Oaks, CA: Pine Forge Press.

Brechin SR (2008) Ostriches and change: A response to 'Global warming and sociology'. Current Sociology 56(3): 467-474.

Brewster BH and Bell MM (2010) The environmental Goffman: Towards an environmental sociology of everyday life. Society and Natural Resources 23(1): 45-57.

Broadbent J (1998) Environmental Politics in Japan: Networks of Power and Protest. Cambridge: Cambridge University Press.

Brunsma DL, Overfelt D and Picou JS (eds) (2007) The Sociology of Katrina: Perspectives on a Modern Catastrophe. New York: Rowman and Littlefield.

Burawoy M (2009) Challenges for a global sociology. Contexts 8(4): 36-41.

Buttel FH (2000) Ecological modernization as social theory. GeoForum 31: 57-65.

Buttel FH (2002a) Environmental sociology and the classical sociological tradition: Some observations on current controversies. In: Dunlap RE, Buttel FH, Dickens P and Gijswijt A (eds) Sociological Theory and the Environment: Classical Foundations, Contemporary Insights. Lanham, MD: Rowman and Littlefield, pp. 35-50.

Buttel FH (2002b) Has environmental sociology arrived? Organization and Environment 15(1): $42-55$.

Buttel FH (2003) Environmental sociology and the explanation of environmental reform. Organization and Environment 16(3): 306-344.

Buttel FH and Humphrey CR (2002) Sociological theory and the natural environment. In: Dunlap RE and Michelson W (eds) Handbook of Environmental Sociology. Westport, CT: Greenwood Press, pp. 33-69.

Calhoun C, Gerteis J, Moody J et al. (2007) Contemporary Sociological Theory, 2nd edn. Oxford: Blackwell.

Carolan MS (2005) Society, biology, and ecology: Bringing nature back into sociology's disciplinary narrative through critical realism. Organization and Environment 18(4): 393-421.

Carolan MS (2006) Conserving nature, but to what end? Conservation policies and the unanticipated ecologies they support. Organization and Environment 19(2): 153-170.

Castells M (2009) The Rise of the Network Society: Volume I of the Information Age. Economy, Society and Culture, 2nd edn. Malden, MA: Wiley-Blackwell.

Catton WR and Dunlap RE (1978) Environmental sociology: A new paradigm. The American Sociologist 13: 41-49. 
Cohen M (ed.) (1999) Risk in the Modern Age: Social Theory, Science and Environmental Decision-making. Basingstoke: Macmillan.

Cohen R and Kennedy P (2013) Global Sociology, 3rd edn. Basingstoke: Palgrave Macmillan.

Couch SR, Kroll-Smith S and Kindler JD (1999) Discovering and inventing hazardous environments: Sociological knowledge and publics at risk. In: Cohen M (ed.) Risk in the Modern Age: Social Theory, Science, and Environmental Decision-making. Basingstoke: Macmillan, pp. 173-195.

Da Costa Ferreira L (2002) Brazilian environmental sociology: A provisional review. Ambiente e Sociedade 5(10): 1-17.

Da Costa Ferreira L, Cal Seixas Barbosa SR, De Moraes Hoefel JL et al. (2006) Environmental issues, interdisciplinarity, social theory and intellectual production in Latin America. Ambiente e Sociedade 9(2): 9-24.

Dickens P (2004) Society and Nature: Changing our Environment, Changing Ourselves. Cambridge: Polity Press.

Dunlap RE (2002) Environmental sociology: A personal perspective on its first quarter century. Organization and Environment 15(1): 10-30.

Dunlap RE (2008) Promoting a paradigm change: Reflections on early contributions to environmental sociology. Organization and Environment 21(4): 478-487.

Dunlap RE and Catton WR (1983) What environmental sociologist have in common (whether concerned with 'built' or 'natural' environments). Sociological Inquiry 53(2-3): 113-135.

Dunlap RE and Michelson W (eds) (2002) Handbook of Environmental Sociology. Westport, CT: Greenwood Press.

Erikson K (1976) Everything in its Path: Destruction of Community in the Buffalo Creek Flood. New York: Simon and Schuster.

Foster JB (1999) Marx's theory of metabolic rift: Classical foundation of environmental sociology. American Journal of Sociology 105(2): 366-405.

Foster JB (2010) Marx's ecology and its historical significance. In: Redclift MR and Woodgate G (eds) The International Handbook of Environmental Sociology, 2nd edn. Cheltenham: Edward Elgar, pp. 106-120.

Foster JB (2012) The planetary rift and the new human exemptionalism: A political-economic critique of ecological modernization theory. Organization and Environment 25(3): 211-237.

Freudenburg WR (2008) Thirty years of scholarship and science on environment-society relationships. Organization and Environment 21(4): 449-459.

Freudenberg WR and Gramling R (1994) Oil in Troubled Waters: Perceptions, Politics, and the Battle of Offshore Drilling. Albany: State University of New York Press.

Freudenburg WR and Gramling R (2011) Blowout in the Gulf: The BP Oil Spill Disaster and the Future of Energy in America. Cambridge, MA: MIT Press.

Freudenberg WR, Frickel S and Gramling R (1995) Beyond the nature/society divide: Learning to think about a mountain. Sociological Forum 10(3): 361-392.

Freudenburg WR, Gramling R, Laska S and Erikson KT (2012) Catastrophe in the Making: The Engineering of Katrina and the Disasters of Tomorrow. Washington, DC: Island Press.

Funabashi H (2006) Minamata disease and environmental governance. International Journal of Japanese Sociology 15(1): 7-25.

Funabashi H (2011) The duality of social systems and the environmental movement in Japan. In: Broadbent J and Brockman V (eds) East Asian Social Movements: Power, Protest, and Change in a Dynamic Region. New York: Springer, pp. 37-61.

Funabashi H (2012) Why the Fukushima disaster is a man-made calamity. International Journal of Japanese Sociology 21(1): 65-75.

Giddens A (1990) The Consequences of Modernity. Cambridge: Polity. 
Giddens A (2009) The Politics of Climate Change. Cambridge: Polity.

Gieryn TF (1999) Cultural Boundaries of Science: Credibility on the Line. Chicago: The University of Chicago Press.

Goldblatt D (1996) Social Theory and the Environment. Cambridge: Polity.

Goldman M and Schurman RA (2000) Closing the 'great divide': New social theory on society and nature. Annual Review of Sociology 26: 563-584.

Gould KA and Lewis TL (2009) Twenty Lessons in Environmental Sociology. York: Oxford University Press.

Gross M (2000) Classical sociology and the restoration of nature: The relevance of Émile Durkheim and Georg Simmel. Organization and Environment 13(3): 277-291.

Gross M and Heinrichs H (eds) (2010) Environmental Sociology: European Perspectives and Interdisciplinary Challenges. Dordrecht: Springer.

Grundmann R and Stehr N (2010) Climate change: What role for sociology? A response to Constance Lever-Tracy. Current Sociology 58(6): 897-910.

Gunther V and Kroll-Smith S (2007) Volatile Places: A Sociology of Communities and Environmental Controversies. London: Pine Forge Press.

Hannigan JA (2006) Environmental Sociology: A Social Constructivist Perspective, 2nd edn. London: Routledge.

Hasegawa K (2012) Facing nuclear risks: Lessons from the Fukushima nuclear disaster. International Journal of Japanese Sociology 21(1): 84-91.

Hasegawa K, Shinohara C and Broadbent JP (2007) The effects of 'social expectation' on the development of civil society in Japan. Journal of Civil Society 3(2): 179-203.

He C (ed.) (2012) Modernization Science: The Principles and Methods of National Advancement. New York: Springer.

Hong D and Xiao C (2007) The growth of Chinese environmental sociology. RC24. Available at: www.bsos.umd.edu/socy/drfisher/isa-rc24/chineseenvironmentalsociology.pdf (accessed 18 October 2013).

Huber J (1982) Die verlorene Unschuld der Ökologie. Neue Technologien und superindustrielle Entwicklung. Frankfurt/Main: Fisher.

Hulme M (2010) Cosmopolitan climates. Hybridity, foresight and meaning. Theory, Culture and Society 27(2-3): 267-276.

Humphrey CR and Buttel FH (1982) Environment, Energy and Society. Belmont, CA: Wadsworth.

Humphrey CR, Lewis TL and Buttel FH (2002) Environment, Energy and Society: A New Synthesis. Belmont, CA: Wadsworth/Thompson Learning.

Iijima N (ed.) (1993) Kankyou Shakaigaku [Environmental Sociology]. Tokyo: Yuhikaku.

Iijima N (1994) Environmental sociology in Japan and environmental problems in Asian societies. International Journal of Japanese Sociology 3(1): 121-130.

Iijima N, Torigoe H, Hasegawa K and Funabashi H (eds) (2001) Perspectives of Environmental Sociology, Environmental Sociology in Japan. Tokyo: Yuhikaku.

Irwin A (1995) Citizen Science: A Study of People, Expertise and Sustainable Development. London: Routledge.

Irwin A (2001) Sociology and the Environment: A Critical Introduction to Society, Nature and Knowledge. Cambridge: Polity.

JAES (Japanese Association for Environmental Sociology) (2006) Environmental Sociology in Japan. Tokyo: JAES.

Jasanoff S (2011) Cosmopolitan knowledge: Climate science and global civic epistemology. In: Dryzek JS, Norgaard RB and Schlosberg D (eds) The Oxford Handbook of Climate Change and Society. Oxford: Oxford University Press, pp. 129-143. 
Kelman A (2003) A River and its City: The Nature of Landscape in New Orleans. Berkeley: University of California Press.

King L and McCarthy D (2009) Environmental Sociology: From Analysis to Action, 2nd edn. Lanham, MD: Rowman and Littlefield.

Kroll-Smith JS and Couch SR (1990) The Real Disasters is above Ground: A Mine Fire and Social Conflict. Lexington: University of Kentucky Press.

Kroll-Smith S, Couch SR and Marshall BK (1997) Sociology, extreme environments and social change. Current Sociology 45(3): 1-18.

$\mathrm{Ku}$ D (2011) The Korean environmental movement: Green politics through social movement. In: Broadbent J and Brockman V (eds) East Asian Social Movements. New York: Springer, pp. 205-229.

Lange H (2002) Social science and nature: A review of environmental sociology in Germany. Natures, Sciences, Sociétés 10(3): 16-26.

Latour B (1993) We Have Never Been Modern. Cambridge, MA: Harvard University Press.

Latour B (2004) The Politics of Nature: How to Bring the Sciences into Democracy. Cambridge, MA: Harvard University Press.

Leahy T (2008) Discussion of 'Global warming and sociology'. Current Sociology 56(3): 475-484.

Lee S and Park J (2002) Environmental sociology in Korea. Environment and Society (Newsletter of Research Committee 24, International Sociological Association), No. 19 (January): 2-5.

Lever-Tracy C (2008a) Global warming and sociology. Current Sociology 56(3): 445-466.

Lever-Tracy C (2008b) Reply. Current Sociology 56(3): 485-491.

Lidskog R (2001) The re-naturalization of society? Environmental challenges for sociology. Current Sociology 49(1): 113-136.

Lin S, Zhao D and Marinova D (2009) Analysis of the environmental impact of China based on STIRPAT model. Environmental Impact Assessment Review 29(6): 341-347.

Lockie S, Sonnenfelt DA and Fisher DR (eds) (2013) Routledge International Handbook of Social and Environmental Change. London: Routledge.

Luhmann N (1989) Ecological Communication. Cambridge: Polity Press (originally published 1986).

McKinney LA (2012) Entropic disorder: New frontiers in environmental sociology. Sociological Perspectives 55(2): 295-317.

McLaughlin P (2012) Ecological modernization in evolutionary perspective. Organization and Environment 25(2): 178-196.

Macnaghten P and Urry J (1995) Towards a sociology of nature. Sociology 29(2): 203-220.

Macnaghten P and Urry J (1998) Contested Natures. London: Sage.

Maohong B (2004) Environmental history in China. Environment and History 10(4): 475-499.

Martell L (1994) Ecology and Society: An Introduction. Cambridge: Polity.

Martell L (2010) The Sociology of Globalization. Cambridge: Policy.

Martin D, Metzger JL and Pierre P (2006) The sociology of globalization: Theoretical and methodological reflections. International Sociology 21(4): 499-521.

Miyauchi T (2006) Pursuing the sociological study of environmental governance in Japan: An introduction to the special issue. International Journal of Japanese Sociology 15(1): 2-6.

Mol APJ (2006) From environmental sociologies to environmental sociology? A comparison of U.S. and European environmental sociology. Organization and Environment 19(1): 5-27.

Mol APJ and Buttel FH (eds) (2002) The Environmental State under Pressure. Amsterdam: Elsevier.

Mol APJ and Spaargaren G (2005) From additions and withdrawals to environmental flows: Reframing debates in the environmental social sciences. Organization and Environment 18(1): 91-107. 
Moon C-I and Lim S-H (2003) Weaving through paradoxes: Democratization, globalization, and environment politics in South Korea. East Asian Review 15(2): 43-70.

Murphy R (2009) Leadership in Disaster: Learning for a Future with Global Climate Change. Montreal and Kingston: McGill-Queen's University Press.

Myoung-Kyu P and Kyung-Sup C (1999) Sociology between western theory and Korean reality: Accommodation, tension and a search for alternatives. International Sociology 14(2): $139-156$.

Nakazawa H (2006) Between the global environmental regime and local sustainability: A local review on the inclusion, failure and reinventing process of the environmental governance. International Journal of Japanese Sociology 15(1): 69-85.

Organization and Environment (2002) Symposium on Environmental Sociology 15(1).

Pellow DN and Nyseth Brehm H (2013) An environmental sociology for the twenty-first century. Annual Review of American Sociology 39: 229-250.

Picou JS, Gill DA and Cohen MJ (eds) (1999) The Exxon Valdez Disaster: Readings on a Modern Social Problem, 2nd edn. Dubuque, IA: Kendall-Hunt.

Redclift M (2000) Environmental social theory for a globalizing world economy. In: Spaargaren G, Mol APJ and Buttel FH (eds) Environment and Global Modernity. London: Sage, pp. $151-162$.

Redclift M (2009) The environment and carbon dependence: Landscapes of sustainability and materiality. Current Sociology 57(3): 369-388.

Redclift M and Benton T (eds) (1994) Social Theory and the Global Environment. London: Routledge.

Redclift M and Woodgate G (eds) (2005) New Developments in Environmental Sociology. Cheltenham: Edward Elgar.

Redclift M and Woodgate G (eds) (2010) The International Handbook of Environmental Sociology, 2nd edn. Cheltenham: Edward Elgar.

Ritzer G (2001) Explorations in the Sociology of Consumption: Fast Food, Credit Cards and Casinos. London: Sage.

Rockström J, Steffen W, Noone K et al. (2009) A safe operating space for humanity. Nature 461: 472-475.

Rosa EA and Richter L (2008) Durkheim on the environment. Ex libris or ex cathedra? Introduction to inaugural lecture to a course in social science, 1887-1888. Organization and Environment 21(2): 182-187.

Sassen S (2006) Sociology of Globalization. New York: WW Norton.

Sassen S (2008) Territory, Authority, Rights: From Medieval to Global Assemblages. Princeton, NJ: Princeton University Press.

Schnaiberg A (2002) Reflections on my 25 years before the mast of the environment and technology section. Organization and Environment 15(1): 30-42.

Spaargaren G, Mol A and Buttel F (eds) (2006) Governing Environmental Flows: Global Challenges to Social Theory. Cambridge, MA: MIT Press.

Studholme M (2007) Patrick Geddens: Founder of environmental sociology. The Sociological Review 55(3): 441-459.

Sunderlin WD (2003) Ideology, Social Theory and the Environment. Lanham, MD: Rowman and Littlefield.

Sutton PW (2004) Nature, Environment, and Society. Basingstoke: Palgrave Macmillan.

Szasz A (2009) Shopping our Way to Safety: How We Changed from Protecting the Environment to Protecting Ourselves. Minneapolis: University of Minnesota Press.

Tàbara JD and Polo D (2006) A passion for environmental sociology: Exploring links between social environmental science, interdisciplinary integration and sustainability with Professor Riley E. Dunlap. Papers: Revista de Sociologi 82: 169-188. 
Urry J (2011) Climate Change and Society. Cambridge: Polity.

Urry J (2013) Societies beyond Oil: Oil Dregs and Social Futures. London: Zed Books.

Van der Sluijs JP, Van Est R and Riphagen M (2010) Beyond consensus: Reflections from a democratic perspective on the interaction between climate politics and science. Current Opinion in Environmental Sustainability 2(5-6): 409-415.

White RD (2004) Controversies in Environmental Sociology. Cambridge: Cambridge University Press.

Wynne B (1996) May the sheep safely graze? A reflexive view of the expert-lay knowledge divide.

In: Lash S, Szerszynski B and Wynne B (eds) Risk, Environment and Modernity: Towards a New Ecology. London: Sage, pp. 44-83.

Wynne B (2001) Creating public alienation: Expert cultures of risk and ethics on GMOs. Science as Culture 10(4): 445-481.

Wynne B (2010) Strange weather, again: Climate science as political art. Theory, Culture and Society 27(2-3): 289-305.

Xiao C and Hong D (2012) Gender and concern for environmental issues in urban China. Society and Natural Resources 25(5): 468-482.

Xiao C, Dunlap RE and Hong D (2012) The nature and bases of environmental concern among Chinese citizens. Social Science Quarterly (online) DOI: 10.1111/j.1540-6237.2012.00934.x

Yearley S (1991) The Green Case: A Sociology of Environmental Issues, Arguments and Politics. New York: Routledge.

Yearley S (1996) Sociology, Environmentalism, Globalization: Reinventing the Globe. London: Sage.

Yearley S (2009) Cultures of Environmentalism: Empirical Studies in Environmental Sociology. Basingstoke: Palgrave Macmillan.

\section{Author biographies}

Rolf Lidskog is Professor in Sociology at Örebro University, Sweden. His main area of interest is environmental policy and politics at the international and national levels, especially the role of expertise and expert bodies in environmental governance. Major recent publications are Transboundary Risk Governance (together with Linda Soneryd and Ylva Uggla; Earthscan, 2010) and Governing the Air: The Dynamics of Science, Policy, and Citizen Interaction (edited together with Göran Sundqvist; MIT Press, 2011).

Arthur PJ Mol is Professor in Environmental Policy at both Wageningen University, the Netherlands, and Tsinghua University, China. He is also director of the Wageningen School of Social Sciences and joint editor of Environmental Politics. His main areas of interest lie within the fields of globalisation, social theory and the environment, informational governance, ecological modernisation, China, sustainable production and consumption and urban environmental governance. Major recent publications are Environmental Reform in the Information Age (Cambridge University Press, 2008), The Ecological Modernization Reader (edited together with David Sonnenfeld and Gert Spaargaren; Routledge, 2009) and China's Local Environmental Politics (edited with Genia Kostka; Routledge, 2014).

Peter Oosterveer is Associate Professor at the Environmental Policy Group at Wageningen University in the Netherlands. After completing his $\mathrm{PhD}$ in 2005, he continued with research and teaching in the field of globalisation and sustainability of food production and consumption. His interests centre in particular on global public and private governance of food for sustainability, including labelling and certification of food in transnational supply chains, and on the role of consumers in promoting sustainability. Recently he has published articles on sustainable palm oil and 
transition processes in food. His experiences include working in Asia (Thailand, Vietnam and China) and Africa (several countries). Among his publications are Food, Globalization and Sustainability (together with David Sonnenfeld; Earthscan, 2012) and Food Practices in Transition: Changing Food Consumption, Retail and Production in the Age of Reflexive Modernity (edited together with Gert Spaargaren and Anne Loeber; Routledge, 2012).

\section{Résumé}

Le débat actuel sur la sociologie de l'environnement porte sur la façon de conceptualiser et d'examiner l'environnement et sur la nécessité de proposer une approche normative et des recommandations politiques. À partir de ce débat, cet article examine le rôle actuel et futur de la sociologie dans le contexte de la mondialisation. II analyse dans quelle mesure les recherches sociologiques de l'environnement aux États-Unis et en Europe diffèrent dans leur compréhension de la contribution de la sociologie à l'étude de l'environnement. Un accent particulier est mis sur les différences entre les deux régions pour ce qui concerne leur utilisation de la tradition sociologique, leur vision de la nature de l'environnement et leurs moyens d'institutionnaliser la sociologie de l'environnement en tant que domaine de recherche. En conclusion, ce travail soulève la question de savoir si les approches actuelles de la sociologie de l'environnement sont appropriées à l'analyse de l'environnement mondialisé et si les origines européennes et nord-américaines de la sociologie de l'environnement la rendent moins pertinente dans un contexte de mondialisation croissante. Enfin, cet article propose de nouvelles règles pour une sociologie mondiale de l'environnement et met en évidence les incidences possibles des études sociologiques sur le changement climatique.

\section{Mots clés}

Changement climatique, mondialisation, sociologie de l'environnement, sociologie mondiale, sociologie publique

\section{Resumen}

Un debate actual sobre la sociología ambiental implica cómo la sub-disciplina debe conceptualizar e investigar el medio ambiente y si debe ser prescriptivo y entregar recomendaciones políticas. Tomando este debate como punto de partida, este trabajo analiza el papel actual y futuro de la sociología en un mundo globalizado. Se discute cómo la sociología ambiental en los EE.UU. y Europa difieren en su comprensión de la contribución de la sociología al estudio del medio ambiente. Se hace hincapié en cómo estas dos regiones difieren con respecto al uso de la tradición del pensamiento sociológico, perspectivas sobre lo que constituye el medio ambiente y las formas de institucionalización de la sociología ambiental como un campo sociológico. En conclusión, se plantea la cuestión de si las versiones actuales de la sociología ambiental son adecuadas para el análisis de un entorno mundial globalizado, o si el fuerte arraigo de la sociología del medio ambiente en las culturas europeas y estadounidenses hacen que sea menos relevante cuando enfrentadas a un mundo cada vez más globalizado. Por último, el trabajo propone algunas nuevas reglas para una sociología del medio ambiente 
mundial y describe algunas de sus posibles implicaciones para el estudio sociológico del cambio climático.

\section{Palabras clave}

Cambio climático, globalización, sociología ambiental, sociología mundial, sociología pública 